MUSSARI Anthony J. (1974). Appointment With Disaster: The Swelling of a Flood. Northeast Publishers, Wilkes-Barre, Pennsylvania: xviii $+158 \mathrm{pp}$., illustr.

SCHNEIDER, William J. \& GODDARD, James E. (1974). Extent and Development of Urban Flood Plains. Geological Survey, Reston, Virginia: Circular 601-J, vii + 14 pp., illustr.

SEWELL, W. R. Derrick (1973). Flood Damage Prevention Planning in Developing Countries. Paper prepared for the U.N. Ad Hoc Group of Experts on Flood Damage Prevention, University of Victoria, Victoria, B.C., Canada: iv + 137 pp. (mimeogr.).

TAYLOR, Gerald G. [1976] . Ecological Aspects of Stream Alterations. Excerpted from the presentation to the Seminar on 'River: Who Gets What, When and Why?' at the University of Connecticut, 15 Sept. 1976. U.S. Fish and Wildife Service, Newton Corner, Massachusetts: 36 pp. (mimeogr., undated).

U.S. Congress House Committee on Government Operations (1971). Hearings Before the Subcommittee on Conservation of Natural Resources, 92nd Congress, 2nd Session, Part 1. Washington, D.C.: 388 pp., illustr.

U.S. Congress House Committee on Government Operations (1973). Stream Channelization: What Federally Financed Draglines and Bulldozers do to OurNation's Streams. House Report No. 93-530, Washington, D.C.: 139 pp.

U.S. Council on Environmental Quality (1978). Our Nation's Wetlands. An Interagency Task Force Report. Participants:
Departments of the Army, Agriculture, Commerce, and Interior, and Environmental Protection Agency. Written by Elinor Lander Horwitz. Government Printing Office, Washington, D.C.: $v+70$ pp., illustr.

U.S. Department of Housing and Urban Development (1978). Office of Federal Disaster Assistance Administration. Pp. 1-3 in Disaster Information, December 1978, Washington, D.C.: $4 \mathrm{pp}$.

U.S. Water Resources Council (1978). Floodplain Management Guidelines. Reprint of 43 FR 6030 of 10 Feb. 1978, Washington, DC: $52 \mathrm{pp}$.

WHITE, Gilbert F., AKIN, Wallace E., BERRY, Brian J. L., BURTON, Ian, DOUGAL, Merwin D., GODDARD, James E., HERTZLER, R. A., HOLMES, Roland C., KATES, Robert W., RENSHAW, Edward F., RODER, Wolf \& SHEAFFER, John R. (1961). Papers on Flood Problems. Research Paper No. 70, Department of Geography, University of Chicago, Chicago, Illinois: vi +240 pp., illustr.

WHITE, Gilbert F., BRINKMAN, Waltraud A. R., COCHRANE, Harold C. \& ERIKSEN, Neil J. (1975). Flood Hazards in the United States: A Research Assessment. Institute of Behavioral Science, University of Colorado, Boulder, Colorado: $141 \mathrm{pp}$, illustr.

WHITE, Theodore H. (1978). In Search of History. Harper \& Row, New York, N.Y.: 561 pp.

WILCOX, William H. (1978). FDAA Prospective. Natural Hazards Observer (Boulder, Colorado), 2(4), pp. 1-2.

\title{
Learning Conservation from the Bedouin
}

Reviving the ancient Bedouin system of rangeland management could help the nations of southwestern Asia to restore the vigour of exhausted grazing-lands. The 'hema' system of reserves is older than the Koran, and until recently it had survived through the centuries largely intact.

An IUCN plan calling for a revival of the 'hema' system was recently presented to middle eastern governments attending a meeting of the United Nations Economic Commission for West Asia (ECWA) in the Syrian capital, Damascus. IUCN's expert on the region, Dr Hartmut Jungius, says 'A modern-day version of the hema system could help governments to combat desertification and improve the standard of living of people in the region'.

Hemas were reserves that were jealously guarded by tribes for a specific purpose. In some hemas, grazing would be allowed only at certain times of the year, or kept in reserve for periods of drought. In others, no grazing would be allowed at all-to protect flowers for bee-keeping or wildlife for hunting. Some hemas were even established specially to protect vital watersheds.

Varying in size from a few hectares to thousands, hemas were often established in a complicated mosaic pattern to protect areas of the dryland ecosystems which harsh experience had taught the tribes it was in their own vital interest to preserve. Says Dr Jungius: 'The Bedouin knew all about the value of conservation centuries before conservationists invented phrases such as "sustainable development" and "rational utilization".'

Widely distributed throughout a broad arc across much of southwestern Asia, the hema system depended for its existence on the desert lore which demanded total respect for other tribes' grazing-rights. Although livestock - principally goats and camels-remain as important now as in the time of the Prophet Moham. med, the hema system has crumbled in the face of population pressures and overgrazing. An additional cause of loss of the system has been the policy-widespread throughout West Asia - of settling nomads.
A recent ECWA report has questioned the wisdom of settling the nomads, commenting that 'animal husbandry as practiced by the Bedouins may be the best adaption to arid land'. Only a fraction of the marginal land used by the nomads is irrigable or suitable even for dryland farming.

The IUCN Report to the 'Expert Meeting on Management, Conservation and Development of Agricultural Resources in the ECWA Region' stresses that the goals of rangeland management and conservation overlap: 'Both aim at providing long-term productivity of the range, the maintenance of a diverse and abundant vegetation cover and, where possible, its restoration and stabilization'.

Hema-like reserves could help to protect the region's highly threatened wild relatives of domestic crops. It is known, for instance, that wild wheat and oats species are threatened by intensification of agriculture and overgrazing. Other wild relatives of crops that are now in urgent need of protection include those of pistachio, lentil, sorghum, and cotton. Consequently the IUCN paper calls for plant reserves to be set up within the managed rangeland. These reserves would also provide undisturbed places for seed production, and in this way would assist in the recovery of degraded rangelands.*

\section{Robert Lamb, Editor of IUCN Bulletin International Union for Conservation of Nature and Natural Resources Avenue du Mont-Blanc 1196 Gland, Switzerland.}

\footnotetext{
*Following attendance at the ECWA meeting, Dr Jungius reported (voce, 22 May 1981) that the proposal to reactivate the hema system as part of the multipurpose use of management areas was warmly welcomed by the meeting in Damascus and was included as a recommendation in their final report, which also called for additional attention to be paid to the conservation of indigenous flora and fauna and the establishment of protected areas.-Ed.
} 